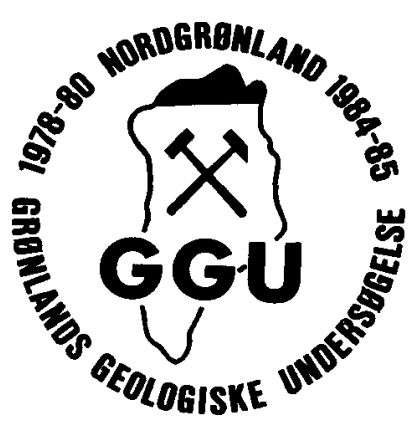

\title{
Geochemical trends in central and western North Greenland
}

\begin{abstract}
Agnete Steenfelt
Geochemical maps and geochemical cross-sections, based on chemical analyses of the $<0.1 \mathrm{~mm}$ fraction of stream sediment samples collected at a density of approximately 1 sample per 30 $\mathrm{km}^{2}$ in central and western North Greenland, show that the distribution patterns for the major elements and some trace elements reflect the main lithological units of the North Greenland Palaeozoic platform and trough. By contrast the distribution patterns for $\mathbf{S}$ and $\mathbf{S r}$ are different. High $\mathbf{S}$ values are correlated with zones of tectonic activity and are thought to indicate migration of $\mathrm{H}_{2} \mathrm{~S}$ along faults. High $\mathrm{Sr}$ values are correlated with evaporitic rocks in the platform sequence and with deep sea carbonates. High $\mathrm{BaO}$ values occurring along the Silurian platform margin and in the Ordovician platform-slope sequence are the result of $\mathrm{Ba}$ enrichment in the sedimentary environment, combined with epigenetic vein-type baryte mineralisation.
\end{abstract}

A. S., Grønlands Geologiske Undersøgelse, Øster Voldgade 10, $D K-1350$ Copenhagen K, Denmark.

Low density sampling of stream sediments for the geochemical mapping of central and western North Greenland was carried out in 1984 and 1985, as reported by Steenfelt (1985) and Jakobsen \& Stendal (1987).

These articles deal mainly with the results for $\mathrm{Ba}$ and $\mathrm{Zn}$ and their significance for the evaluation of the ore potential. The present contribution discusses the relationships of the regional geochemical pattern to the main rock units, and gives examples of the use of stream sediment data in geological interpretation. The chemistry of stream sediment is very close to the chemistry of the surrounding rocks in dry arctic climates (Steenfelt \& Kunzendorf, 1979), and hence the results are here treated as representative of the rock geochemistry.

The region covered by the investigation consists of Precambrian crystalline basement overlain by a Lower Palaeozoic carbonate shelf and clastic trough sequence (Henriksen, 1987) (fig. 2a). The area was subsequently affected by the Ellesmerian orogeny (DevonianCarboniferous) and by the Eurekan orogeny (late Cretaceous) (Higgins et al., 1985).

The stream sediment samples were collected at a density of 1 sample per $30 \mathrm{~km}^{2}$ throughout the region shown in fig. 1 . The $<0.1 \mathrm{~mm}$ fraction of the samples was analysed by XRF for 30 elements by Sveriges Geologiska AB. Details of sampling methods were described by Steenfelt (1985). 


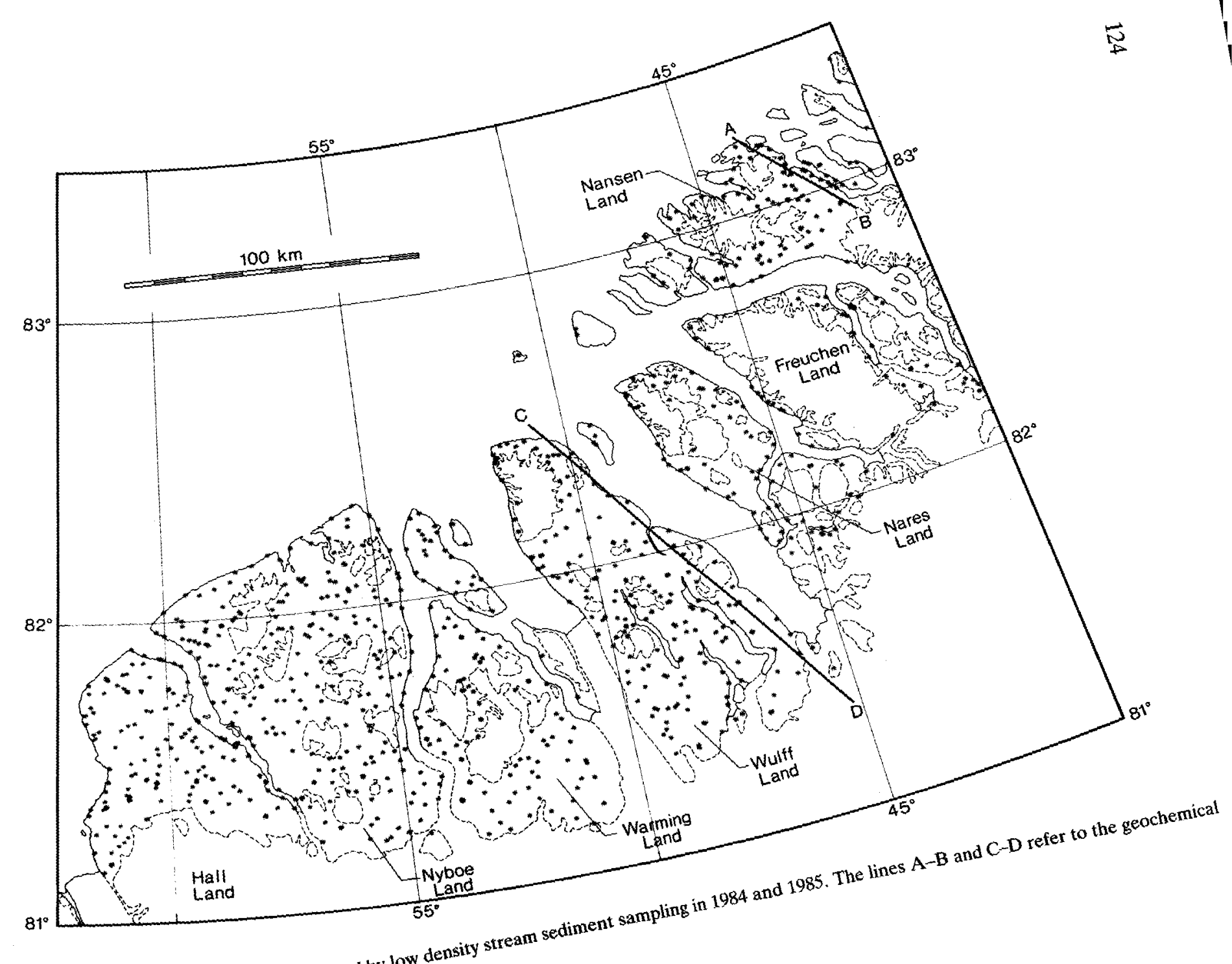

Fig. 1. Sample loca

sections of fig. 3 . 


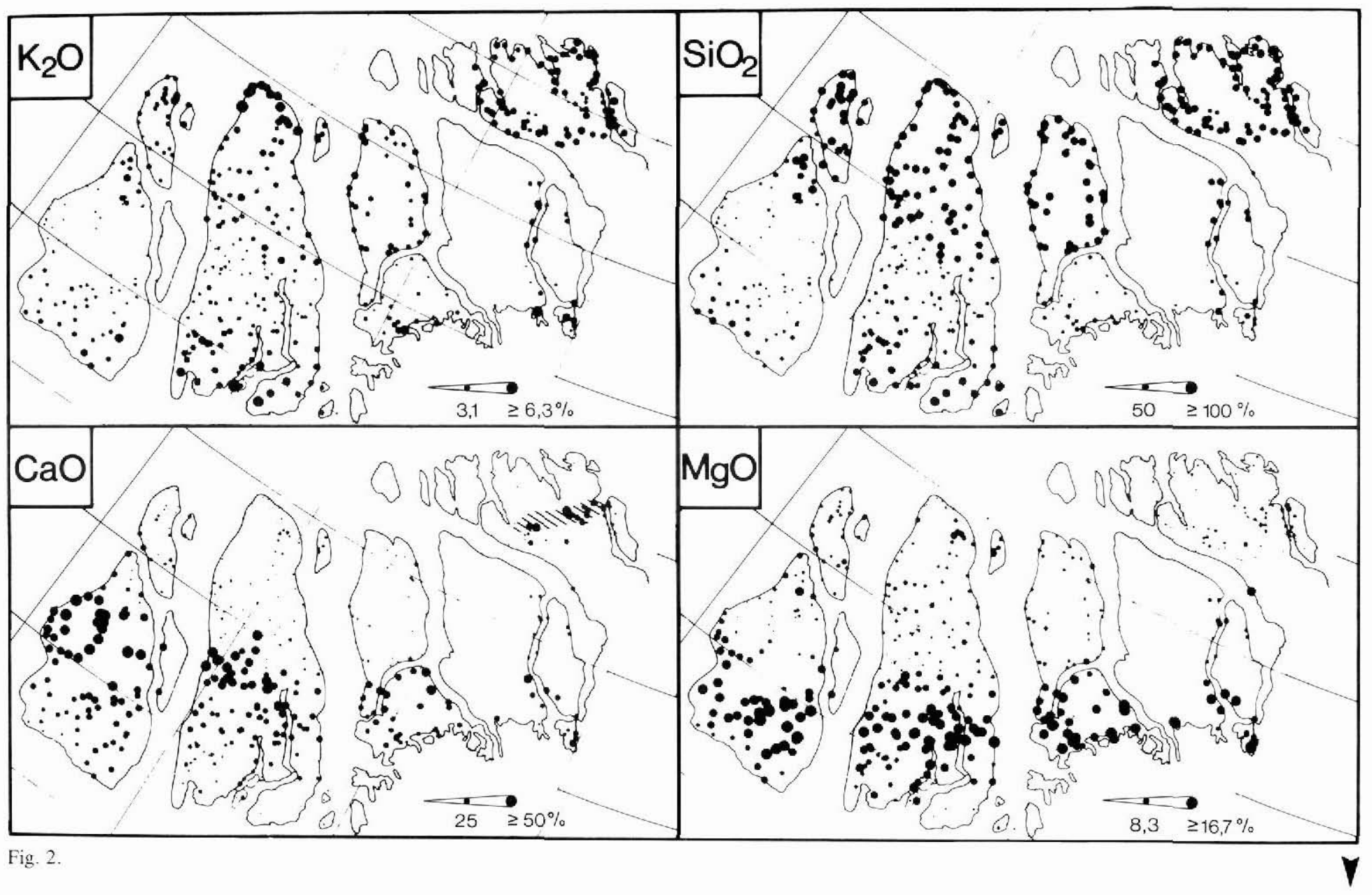




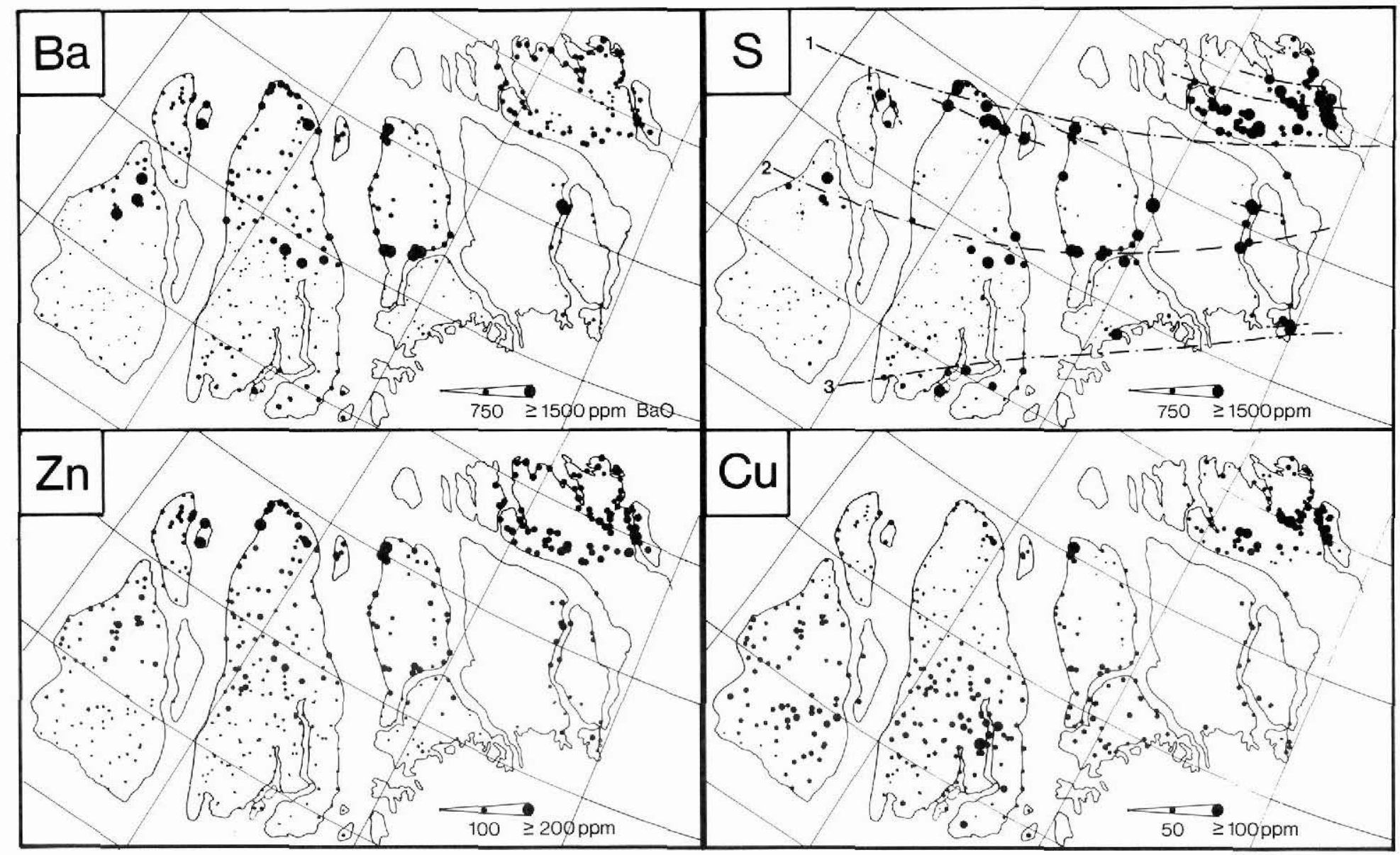

Fig. 2. 

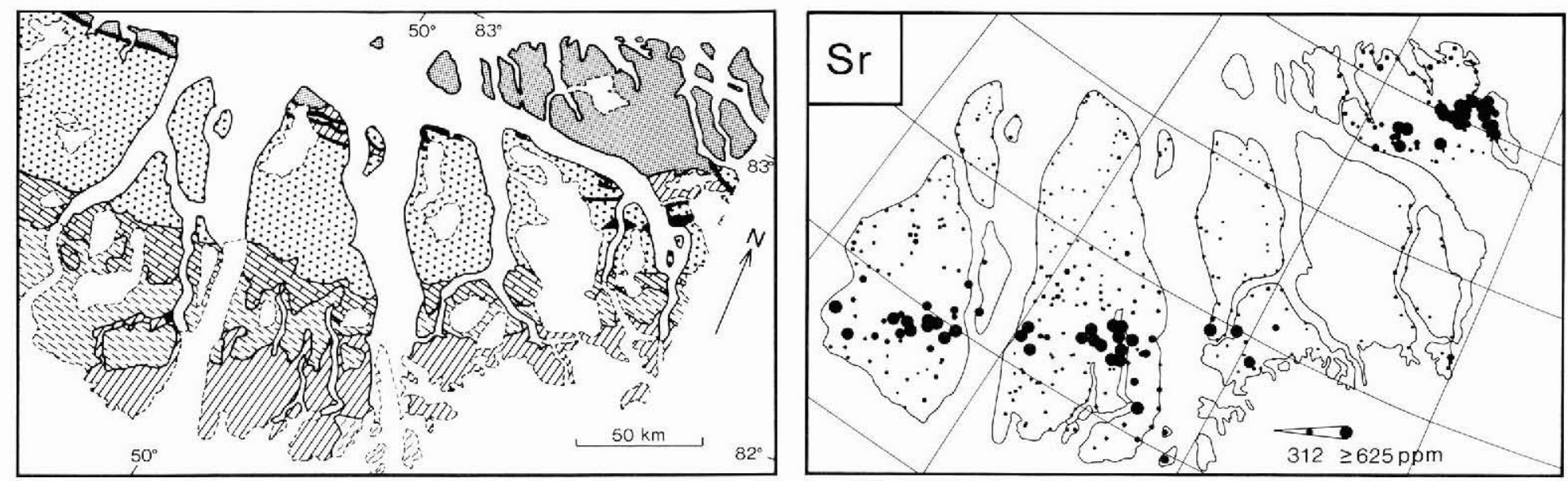

Deep water sequence

$\because \ldots$ Silurian

Platform sequence

Middle Cambrian -

Lower Silurian

Silurian

2,5 Precambrian gneisses

Lower Cambrian

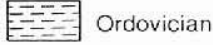

VIIID Cambrian

Ice

Fig. 2. Symbol maps showing the concentration of elements in the $<0.1 \mathrm{~mm}$ fraction of stream sediment samples in the 1984 sampling area. Simplified geological map of the region, after Henriksen (1987). In the CaO map the Paradisfjeld Group is shown by line-shading. In the $\mathrm{S}$ map dash-dot lines indicate the approximate position of major fault and thrust systems (A. K. Higgins and H. F. Jepsen, personal communications, 1985). The dashed line (2) marks the position of the Silurian platform margin. 


\section{Results}

\section{Geochemical maps}

Symbol maps illustrating the concentration of chemical elements at each sampling point are under production for samples collected in 1984 and 1985. The Geological Survey of Greenland (GGU) plans to publish a geochemical atlas containing symbol maps for all elements, covering that part of North Greenland shown in fig. 1.

Fig. 2 shows examples of maps from the region sampled in 1984, together with a simplified geological map for comparison (Henriksen, 1987). The pattern shown by major elements, such as high $\mathrm{SiO}_{2}, \mathrm{~K}_{2} \mathrm{O}$ and low $\mathrm{CaO}$ and $\mathrm{MgO}$, reflects the differences in lithology in the clastic sediments in the south (Lower Cambrian shelf clastics) and in the north (most of the trough sequence), whereas high $\mathrm{CaO}$ and $\mathrm{MgO}$ prevail in the carbonate platform sequence. The area of high $\mathrm{CaO}$ readings in the north corresponds to the outcrop of the deep-water carbonates of the Paradisfjeld Group (Friderichsen \& Bengaard, 1985).

The distribution patterns for the trace elements show greater variation. The figure gives 4 examples in which $\mathrm{Ba}, \mathrm{Cu}$ and $\mathrm{Zn}$ largely display the same kind of pattern as the major elements, whereas the distribution of $S$ differs. High $S$ values are located in narrow zones, indicating that the distribution of $S$ is governed by factors other than the gross scale lithology; these will be discussed later.

Another trace element with a specific distribution pattern is Sr. A belt of very high Sr values (1300 ppm to $5000 \mathrm{ppm}$ ) crosses Warming Land, Wulff Land and Nares Land, and can be correlated with evaporites of the Middle Ordovician Cape Webster Formation of the carbonate platform sequence (Peel, 1980; Sønderholm \& Due, 1985). The Sr values decrease across Nares Land, in accordance with the gradation of the Cape Webster Formation into the dolomitic Wandel Valley Formation (Peel, 1982).

High Sr values ( $500 \mathrm{ppm}$ to $1000 \mathrm{ppm}$ ) are also associated with the Lower Cambrian deepwater carbonates of the Paradisfjeld Group in Nansen Land (same area as high $\mathrm{CaO}$ readings in Nansen Land in fig. 2). By comparison, the dolomites and limestones of the CambroSilurian platform normally contain less than $400 \mathrm{ppm}$ Sr.

Veizer \& Demovič (1974) presented a facies classification of carbonate rocks in the Carpathians based on the $\mathrm{Sr} / \mathrm{Ca}$ ratios. Bank or shelf facies had low $\mathrm{Sr} \times 1000 / \mathrm{Ca}$ ratios, from 0.15 to 0.6 , deep sea carbonate rocks had high $\mathrm{Sr} \times 1000 / \mathrm{Ca}$ ratios, from 0.4 to 3.0, and lagoon facies rocks also rather high ratios of 2.0 to 5.0 .

In North Greenland the $\mathrm{Sr} \times 1000 / \mathrm{Ca}$ ratio in stream sediment samples from the carbonate platform varies from 0.6 to 2.6, in the Paradisfjeld Group from 2.6 to 4.6, and in the Cape Webster Formation from 5 to 10 ; this is in good agreement with the classification of Veizer \& Demovič (1974), and demonstrates the usefulness of stream sediment geochemical data for confirmation and interpretation of sedimentary facies.

\section{Geochemical cross sections}

In a geochemical cross-section the variations in element concentrations can be displayed more accurately, and the correlation between the elements can be studied. Fig. 3 shows a geochemical cross-section through North Greenland for 7 elements, with the geology shown along the section lines. The diagram is constructed by projecting sample points within a 15 
km wide corridor onto section lines A-B and C-D (fig. 1), which are approximately at right angles to the long axis of the shelf and basin.

The variation in the major elements illustrates well the main lithological changes, as well as changes in litho-facies. For example, the predominance of dolomite in the southern part of the Cambro-Silurian platform sequence $(\mathrm{MgO}>\mathrm{CaO})$ and of limestone in the northern part $(\mathrm{CaO}>\mathrm{MgO})$. Mudstone and shale are reflected by high $\mathrm{K}_{2} \mathrm{O}$. For example, the increase in $\mathrm{K}_{2} \mathrm{O}$ at the Silurian platform margin in central Wulff Land reflects the mudstone of the Lafayette Bugt and Wulff Land Formations (Hurst \& Surlyk, 1982; Larsen \& Escher, 1985), and the high $\mathrm{K}_{2} \mathrm{O}$ in northernmost Wulff Land and Nansen Land reflects the silty shales of the Polkorridoren Group (Friderichsen \& Bengaard, 1985).

As in the geochemical maps, most of the trace element variation displayed by the geochemical cross-section can be accounted for by the changes in lithology. The variation in $\mathrm{BaO}$ and $\mathrm{Zn}$ illustrates this, and further shows that there is a good correlation between the two elements, except in the Cambrian Paradisfjeld Group carbonates in Nansen Land (A-B), where the relative enrichment in $\mathrm{Zn}$ needs additional explanation. $\mathrm{BaO}$ shows a good correlation with $\mathrm{K}_{2} \mathrm{O}$, indicating that $\mathrm{BaO}$ is enriched in the shales and mudstones.

The variation in S (as observed also in the symbol maps) is poorly correlated with the other elements. High $S$ is particularly seen at the Silurian shelf margin in the Wulff Land anticline (to the left in section C-D), and in Nansen Land (section A-B).

\section{Discussion}

A high content of $\mathbf{S}$ in stream sediment samples may reflect the occurrence of bituminous rock units rich in organogene $\mathrm{S}$, or mineralisations with sulphides or sulphates. The black bituminous shales along the Silurian shelf margin (Lafayette Bugt and Wulff Land Formations) and in the Cambrian - Lower Silurian un-named shelf and slope sequence would be expected to have somewhat elevated S contents. However, the pyrite accumulations in the rocks, both stratabound and discordant, are so pronounced that they possibly indicate a mineralising event of, for example, a submarine-exhalative nature as discussed by Jakobsen \& Stendal (1987). The symbol maps and the geochemical cross-section show that high $S$ values typically coincide with the occurrence of faults. Surlyk \& Hurst (1984) consider that the successive positions of the shelf margin were controlled by deep-seated, regional east-west faults. Pyrite accumulation is not only observed in bituminous shale units; cavity fillings and impregnations with pyrite also occur in dolomite of the Ryder Gletscher Group (or equivalent Brønlund Fjord and Tavsens Iskappe Groups (Peel \& Wright, 1985)), which is intersected by the regional fault in the south (no. 3 in S map of fig. 2), as well as in dolomite of the Portfjeld Formation in northern Wulff Land and eastern Freuchen Land. It is therefore suggested that $\mathrm{S}$, presumably in the form of $\mathrm{H}_{2} \mathrm{~S}$ of either volcanic or organic origin, migrated along the faults and enriched the surrounding rocks. The influx of $S$ must have taken place both during and after the sedimentation, as the pyrite mineralisation is stratabound as well as discordant.

The reasons for the $\mathrm{BaO}$ and $\mathrm{Zn}$ anomalies in the analytical results from the 1984 samples were discussed by Steenfelt (1985). The results of the 1985 sampling have not yet been fully treated, but preliminary data show that the zone of high $\mathrm{BaO}$ values along the Silurian platform margin continues to the west through Nyeboe Land and Hall Land. A stream sediment sample from south-west Nyeboe Land contained about $2 \% \mathrm{BaO}$, and a mineralogical exam- 
Fig. 3. Geochemical cross-section through North Greenland. The position of section lines A-B and C-D are shown in fig. 1. The symbols show the element concentration in the $<0.1 \mathrm{~mm}$ fraction of stream sediment samples along the section line. The simplified geology along the section is shown at the bottom. PREC.: Precambrian crystalline basement. PO: Portfjeld Formation. BU: Buen Formation. C-S CARB: Cambro-Silurian carbonate shelf. SIL.: Silurian. PA.: Paradisfjeld Group. 1, 2, 3, 5: individual units of the Polkorridoren Group (Friderichsen \& Bengaard, 1985).

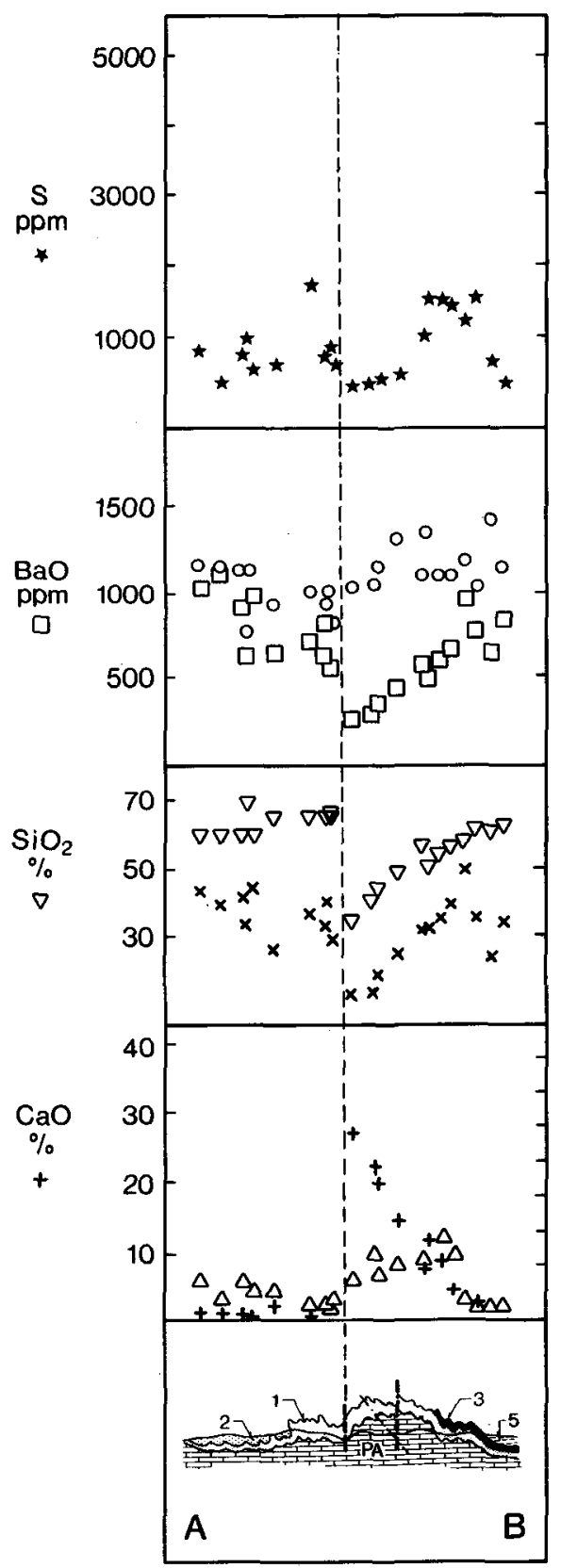




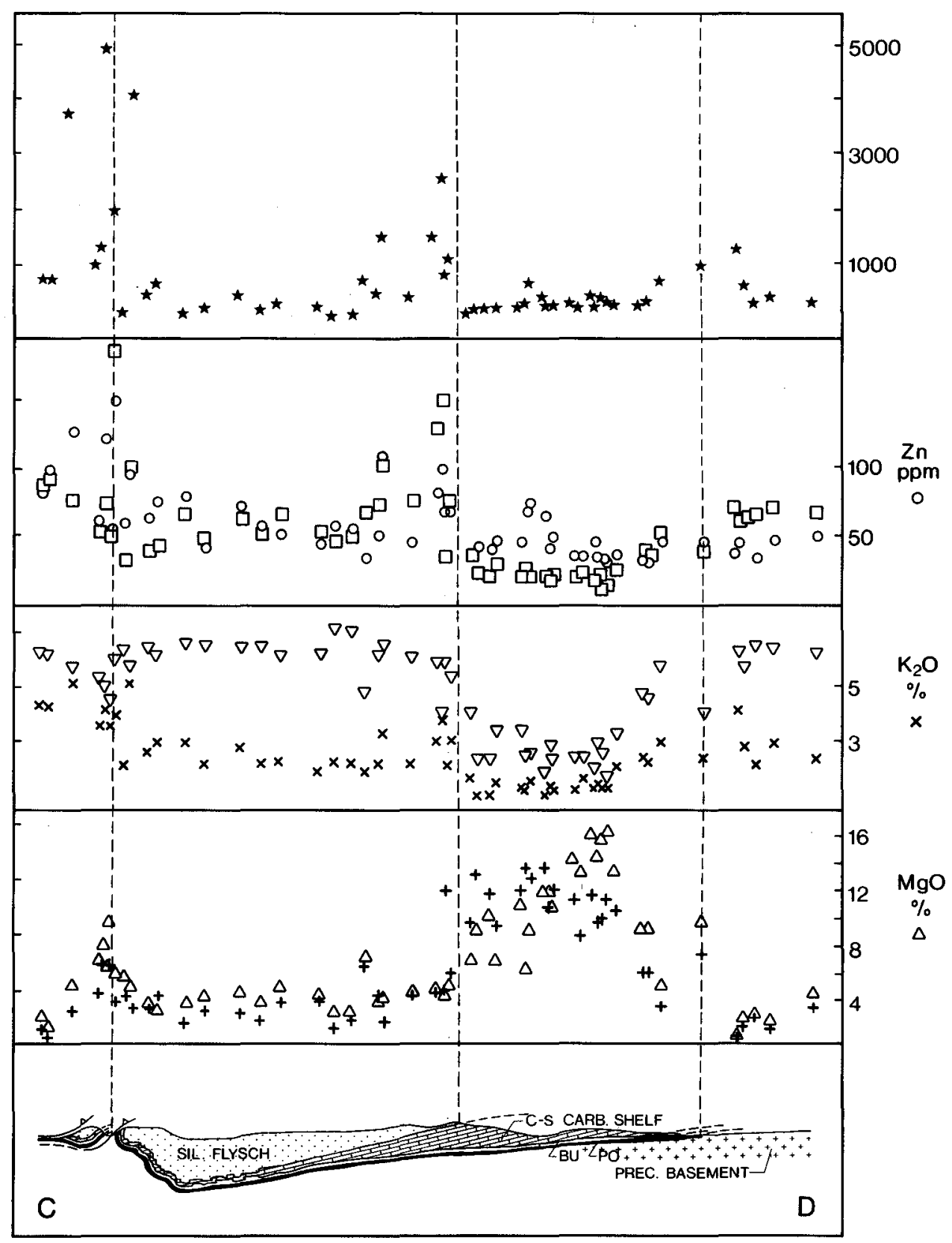


ination showed that baryte is a major constituent. It is thus established that vein-type Ba mineralisation does occur along the platform margin, although a considerable proportion of the increased values is ascribed to Ba enrichment in the shale environment (Lafayette Bugt and Wulff Land Formations), as indicated by the geochemical cross-section (fig. 3), and discussed by Jakobsen \& Stendal (1987). There appears to be a similar situation with respect to $\mathrm{BaO}$ and $\mathrm{Zn}$ associated with the Cambro-Silurian deep-water un-named shelf and slope sequence, namely an enrichment in the sedimentary environment and, in addition, a vein-type hydrothermal mineralising event (Steenfelt, 1985; Jakobsen \& Steenfelt, 1985; Jakobsen \& Stendal, 1987).

\section{References}

Friderichsen, J. D. \& Bengaard, H. J. 1985: The North Greenland fold belt in eastern Nansen Land. Rapp. Grønlands geol. Unders. 126, 69-78.

Henriksen, N. 1987: Systematic geological mapping in 1985 in central and western North Greenland. Rapp. Gronlands geol. Unders. 133,5-12.

Higgins, A. K., Soper, N. J. \& Friderichsen, J. D. 1985: North Greenland fold belt in eastern North Greenland. In Gee, D. C. \& Sturt, B. A. (edit.) The Caledonide Orogen - Scandinavia and related areas, 1017-1029. John Wiley \& Sons.

Hurst, J. M. \& Surlyk, F. 1982: Stratigraphy of the Silurian turbidite sequence of North Greenland. Bull. Grønlands geol. Unders. 145, 121 pp.

Jakobsen, U. H. \& Steenfelt, A. 1985: Zinc mineralisation at Navarana Fjord, central North Greenland. Rapp. Gronlands geol. Unders. 126, 105-109.

Jakobsen, U. H. \& Stendal, H. 1987: Geochemical exploration in central and western North Greenland. Rapp. Grønlands geol. Unders. 133, 113-121.

Larsen, P.-H. \& Escher, J. C. 1985: The Silurian turbidite sequence of the Peary Land Group between Newman Bugt and Victoria Fjord, western North Greenland. Rapp. Grønlands geol. Unders. 126, 47-67.

Peel, J. S. 1980: Cambrian and Ordovician geology of Warming Land and southern Wulff Land, central North Greenland. Rapp. Grønlands geol. Unders. 101, 55-60.

Peel, J. S. 1982: The lower Paleozoic of Greenland. In Embry, A. F. \& Balkwill, H. R. (edit.) Arctic geology and geophysics. Mem. Can. Soc. Petrol. Geol. 8, 309-330.

Peel, J. S. \& Wright, S. C. 1985: Cambrian platform stratigraphy in the Warming Land-Freuchen Land region, North Greenland. Rapp. Grønlands geol. Unders. 126, 17-24.

Steenfelt, A. 1985: Reconnaissance scale geochemical survey in central and western North Greeenland. Preliminary results concerning zinc and barium. Rapp. Grønlands geol. Unders. 126, 95-104.

Steenfelt, A. \& Kunzendorf, H. 1979: Geochemical methods in uranium exploration in northern East Greenland. In Watterson, J. R. \& Theobald, P. K. (edit.) Geochemical exploration 1978. Proceedings 7th Int. Symp. Exploration Geochemistry, 429-442. Association of Exploration Geochemists.

Surlyk, F. \& Hurst, J. M. 1984: The evolution of the early Paleozoic deep-water basin of North Greenland. Bull. Geol. Soc. Am. 95, 131-154.

Sønderholm, M. \& Due, P. H. 1985: Lower and Middle Ordovician platform carbonate lithostratigraphy of Warming Land, Wulff Land and Nares Land, North Greenland. Rapp. Grønlands geol. Unders. 126, 31-46.

Veizer, J. \& Demovič, R. 1974: Strontium as a tool in facies analysis. J. sed. Petrol. 44, 93-115. 